\title{
AUTORITARISMO E VIOLÊNCIA NAS LITERATURAS DE LÍNGUA PORTUGUESA: GRACILIANO RAMOS, BRANQUINHO DA FONSECA E LUÍS BERNARDO HONWANA
}

\author{
AUTHORITARIANISM AND VIOLENCE IN \\ PORTUGUESE-LANGUAGE LITERATURES: \\ GRACILIANO RAMOS, BRANQUINHO DA \\ FONSECA AND LUÍS BERNARDO HONWANA
}

Keli Cristina Pacheco ${ }^{1}$

\section{RESUMO}

Neste artigo realizamos um exercício de literatura comparada das obras $V i$ das Secas (1938), de Graciliano Ramos, Nós matamos o Cão-Tinhoso (1964), de Luís Bernardo Honwana, e Bandeira Preta (1956), de Branquinho da Fonseca, com a intenção de refletir principalmente sobre a presença da violência nos enredos. Procuramos não estabelecer um centro de influência, conforme solicita Silviano Santiago (1971), a fim de considerar alguns sentidos das construções ficcionais, notadamente em relação à linguagem e à forma narrativa, a partir do exercício comparativo. Também buscamos perscrutar o modo como as personagens recepcionam as paisagens históricas, ou ainda identificar a forma como resistem à violência presente nelas. PALAVRAS-CHAVE: literatura comparada; literaturas de língua portuguesa; violência.

\section{ABSTRACT}

In this article we perform an exercise of comparative literature of the works Vidas Secas (1938, Barren Lives), by Graciliano Ramos, Nós matamos o Cão-Tinhoso (1964, We killed Mangy Dog), by Luís Bernardo Honwana, 
and Bandeira Preta (1956, Black Flag), by Branquinho da Fonseca, in order to think, mainly, about the presence of violence in their plots. The intention is not to establish a center of influence, as we are following Silviano Santiago's request [2000(1971)], but to considerate some senses of those fictional constructions, notably what is related to language and the narrative form, from the comparative exercise. We also seek to peer how the characters receive the historical landscapes, or yet to identify how they resist to the violence present on those landscapes.

KEYWORDS: Comparative literature; Portuguese-lenguage literature; violence.

René Wellek, no final de década de 1950, ao escrever sobre a literatura comparada, aborda seu contexto de escrita, a crise permanente no mundo após 1914. Justamente após o fim da segunda guerra mundial, quando uma das grandes catástrofes humanas se fez visível, o teórico se ergue solicitando e sugerindo uma saída para "A crise da literatura comparada" (título de seu ensaio). Contaminada pelo aparato epistemológico-discursivo da antropologia científica - que sustentou a segunda guerra, e também o neocolonialismo -, e diante dos resultados originados, a literatura comparada não ficou isenta de sofrer uma avaliação crítica; porém, em seu texto Wellek, de algum modo, ainda está contaminado por um método bastante científico de montagem argumentativa, em que descreve um problema, elabora um diagnóstico e receita uma cura, e na ocasião solicita aos pesquisadores, como um bom textualista, um retorno à literariedade.

Das lições que lega, há uma demanda pela não redução da disciplina de literatura às balizas nacionais, esta já adotada em muitos currículos de Letras, e um pedido, aos estudiosos da área de literatura, de menos senso de propriedade, uma vez que Wellek acredita no olhar do não especialista como sendo fonte de uma possível sensibilidade e maior raio de ação, "cuja perspectiva mais ampla e discernimento mais agudo podem muito bem suprir anos de intensa dedicação" (WELLEK, 1994, p. 116). Em muitos currículos, as disciplinas de literatura abandonaram o critério nacional, substituindo-o pelo critério linguístico, e a presença da língua portuguesa como língua oficial nos territórios passa, portanto, a ser ponto que une distintas literaturas e culturas, fazendo da prática comparatista um campo profícuo que possibilita o trabalho criativo do professor não-especialista em algumas dessas literaturas, ao menos, desde que não se caia na armadilha de criar hierarquia entre as nações, como através da noção de fonte-influência, por exemplo. ${ }^{2}$

Rita Chaves (2006), entre outros pesquisadores, já escreveu sobre a presença da literatura brasileira, principalmente a partir de 1940, na formulação do imaginário nacionalista africano. ${ }^{3}$ Salvato Trigo (1984), teórico português, menos de 10 anos após as descolonizações dos países africanos 
de língua portuguesa, também reconhece, principalmente nas décadas de 30 e 40, a presença considerável da literatura brasileira nos países africanos que têm a língua portuguesa como oficial, vendo nela uma forma de o colonizado afirmar a sua diferença ante o sistema estético-político que o dominava. Diferente de Rita Chaves, que solicita que conheçamos a literatura africana por conta da dívida histórica com os povos que espoliamos, Salvato Trigo percebe que estudar uma literatura é de certa forma estudar a outra, porém a brasileira ainda pouco reconhece a presença das literaturas africanas em seu próprio corpo.

Mais recentemente, Alfredo de Mello (2016) visualiza que o estudo das literaturas africanas em língua portuguesa, em perspectiva comparada, desestabiliza o pressuposto de que a literatura é uma instituição criada na Europa; para o estudioso, não há um centro de irradiação, há a revelação de outros roteiros que merecem ser estudados.

Literatura é comunicação em permanente transformação. Em seu recente Enlightenment Orientalism, Srinivas Aravamudadan argumenta que não se pode explicar a ascensão do romance na Europa sem levar em conta as narrativas orientais (oriental tales) que circulavam pelo Velho Continente no século 18. Aravamudan vai de encontro às versões exclusivamente europeias da origem do romance. (MELLO, 2016, p. 53)

Antes ainda é preciso lembrar que, em relação à forma narrativa do romance, Benjamin, em "O narrador", ao estudar a obra de Nikolai Leskov, já identificava a forma romanesca como testemunho da morte do primitivo narrador oral, presente nas mais diversas tradições, deixando assim movediço o espaço de surgimento do romance, sua possibilidade de pertença a uma única tradição.

Sob a perspectiva comparatista, e sem o estabelecimento de um centro de influência, no presente artigo procuraremos assinalar alguns elementos/imagens que marcam aproximações e diferenças entre três obras das literaturas de língua portuguesa. Para isso tomamos Vidas Secas (1938), de Graciliano Ramos, Nós matamos o Cão-Tinhoso (1964), de Luís Bernardo Honwana, ${ }^{4}$ e Bandeira Preta (1956), de Branquinho da Fonseca, ${ }^{5}$ com a intenção de refletir principalmente sobre os temas da autoridade e do autoritarismo presentes nos diferentes enredos.

Há uma convergência entre as três narrativas no que tange ao aspecto formal e temático. Em relação a este último, em Vidas Secas, narrativa mais reconhecida das três pelo público brasileiro, temos a história de uma família à margem da história. De igual modo, em Nós matamos o Cão-Tinhoso, temos uma série de narrativas em que o narrador em primeira pessoa ${ }^{6}$ é criança ou adolescente ou, quando em terceira pessoa, como é o caso do narrador do conto "Dina", mira seu foco narrativo para idosos, mulheres e animais, em ambientes pobres e de exploração, todos igualmente à margem da história. Em Bandeira Preta, por sua vez, temos um grupo de crianças vivendo em meio rural até a chegada à adolescência, com um 
narrador bastante devotado na descrição do ponto de vista que parte do olhar infantil que, como sabido, são sujeitos em vulnerabilidade potencializada em contextos violentos.

Quanto ao aspecto formal, os três livros podem ser considerados romances ou contos, porém certamente há uma autonomia dos capítulos de forma mais radical em Nós matamos o Cão-Tinhoso, notadamente por apresentar distintas personagens - diferente da obra de Ramos e Fonseca, que mantêm as mesmas personagens -, ao passo que o pano de fundo de violência colonial une as narrativas, que fora do conjunto perderiam a sua potência caleidoscópica, como concorda Maria Alzira Seixo, ao afirmar que o livro é composto por sete contos e

[...] que apresentam implicitamente como parcelas de uma mesma narrativa, larga e impossível, apenas concretizável em fragmentos ou intuições de instantes, adivinhando-se cruel o seu desdobramento coerente, impressionante o saldo das suas significações subjetivas. (1973, p. 82)

Luís Bueno, ao escrever Uma história do romance de 30, no capítulo no qual se dedica à obra de Graciliano Ramos, observa que o problema da representação que se pode fazer do outro sai do aspecto da tematização dos conflitos para a estrutura narrativa (BUENO, 2006, p. 641-642). Bueno, então, ao tratar de Vidas Secas, engendra uma discussão a partir da nomenclatura dada pela fortuna crítica em relação à estrutura narrativa: seria em políptico? Rosácea? Trata-se de um livro de contos ou de um romance desmontável? Para responder à questão, o crítico percorre os capítulos e observa que há um vínculo de resposta entre eles, criando um movimento, apesar de toda imutabilidade da família em face do poder e da miséria. A imagem, para Bueno, é de uma espiral que lança as personagens em um ciclo de exploração (BUENO, 2006, p. 663-664). De igual modo, porém em diferentes contextos, nas narrativas de Honwana e Fonseca também é possível vislumbrar a mesma mutabilidade imutável, no desenho de suas narrativas, ante um poder que se impõe em diferentes contextos às personagens.

Ao afastar o rótulo de romance regionalista das obras do que chama fase madura de Graciliano Ramos, Belmira Magalhães argumenta que o foco principal de sua ficção é expor a situação "de homens, mulheres e crianças se relacionando, regidos pela lógica do sistema capitalista, na periferia desse sistema, que prioriza relações pré-capitalistas de exploração" (MAGALHÃES, 2010, p. 43). Nessa perspectiva, podemos incluir também a obra de Fonseca e Honwana como exercícios de denúncia de um sistema que se impõe aos que estão fora dele.

Há um elemento em Bandeira Preta, ausente em Vidas Secas e em de Nós matamos o Cão-Tinhoso, bastante significativo como traço distintivo das obras: trata-se da presença da tradição oral. No conto "O Ninho", por exemplo, há trechos de cantigas das raparigas nas eiras, em outros vemos excertos de cantigas infantis e alguns ditos populares. Os capítulos "Histó- 
rias da Meia-Noite" e "Maria-Francesa" são basicamente compostos de narrativas orais, fazendo-nos vislumbrar um lastro da identidade portuguesa e um exercício de preservação dessa cultura no registro do autor. Contudo, a ausência desse elemento nas narrativas de Ramos e Honwana, que se passa em regiões povoadas por personagens que carregam todo um saber oral, significa. Irenísia Torres de Oliveira, ao estudar os livros sertanejos de Graciliano Ramos, escreve sobre essa falta em Vidas Secas, e vê nela uma motivação estética, pois a aparição de qualquer fantasia, causos, histórias, ligados à tradição oral, "poderiam trazer alguma diluição ou aparente alívio à situação profunda, que era alarmante” (OLIVEIRA, 2010, p. 65).

Em Vidas Secas, a única passagem em que um exercício de narrativa floresce acontece no inverno, comumente estação hostil para o homem; no sertão, mundo às avessas, é época das chuvas, propiciando o aparecimento de certo otimismo nas personagens. Em meio à sensação de desconforto dos meninos, deitados no colo da Sinhá Vitória, o pai contava façanhas sentindo-se "capaz de atos importantes". Tal passagem é reveladora, pois atesta que a narrativa surge como sintoma de certas condições mínimas, ou precisamente, ela, a narrativa, floresce quando a vida não está em risco. "Não havia o perigo da seca imediata, que aterrorizara a família durante meses" (RAMOS, 1992, p. 65). Nesse viés, conforme Oliveira, o mundo encantado das narrativas orais é encarado como compensatório, como complementa:

Esta visão distancia-se daquela outra, mais otimista e simpática, que considera a cultura popular como riqueza a ser preservada, ou uma espécie de lastro de nacionalidade. A diferença está em que a pergunta pela literatura oral diz respeito agora ao seu papel entre o próprio povo, que a produz e reproduz. Ou seja, aqui não está em vista o seu papel na construção da nacionalidade, do ponto de vista das elites letradas, mas sua função social no meio de origem. (OLIVEIRA, 2010, p. 67) ${ }^{8}$

Podemos estender essa percepção à obra de Honwana, como já afirmamos acima, uma vez que esta também não apresenta narrativas da cultura oral, apenas mescla de palavras próprias da oralidade, em língua do grupo banto, como em "Nhinguitimo", por exemplo, que reforçam a multiplicidade de grupos etnolinguísticos presentes em Moçambique e expressa o quanto as personagens dominadas também são marginalizadas, não só pela cor da pele ou por sua classe social, mas por não dominarem a língua portuguesa, "instrumento do progresso", "expressão da soberania nacional", e "tragicamente, uma língua minoritária" em Moçambique, como afirma o próprio Honwana em artigo (2006, p. 22-23). ${ }^{9}$

Dentre os três livros comparados aqui, Nós matamos o Cão-Tinhoso expõe situações mais violentas, apresenta uma degradação do humano ainda maior (se for possível mensurar isso) do que Vidas Secas, salientado pela impotência de algumas personagens diante do horror. Como exemplo, 
citamos "Dina" e "Nhinguitimo": no primeiro, o pai, explorado e miserável, vê a filha se prostituindo com o seu capataz; no segundo, um jovem que tem sua força de trabalho explorada enlouquece, mata os seus companheiros e o "patrão", sem titubear, manda abatê-lo, tal como um animal. ${ }^{10}$

Sabidamente, em Vidas Secas temos acesso à "não-vida" de uma família de retirantes através de um narrador que descreve, em uma linguagem considerada seca, ${ }^{11}$ limpa, telegráfica, o outro famélico, seja ele figurado em um animal, em uma mulher ou em crianças, que ele toca, mas não se identifica, como afirma Bueno (2006). Ramos não cria um narrador que representa os sem língua, como o faz Jorge Amado, por exemplo, mas apenas dá acesso às "não-vidas", através de uma "descrição extensiva do real" (OLIVEIRA, 2010, p. 65). Nesse sentido, constrói o que Giorgio Agamben denomina testemunho, pois não fala em lugar do outro, mas dá condições de o outro vir à luz em sua singularidade e irredutibilidade, revelando, através de seu testemunho, a impossibilidade dessa outra voz aceder, de esse testemunho real e verdadeiro nos alcançar.

Richard Sennett, em seu estudo sobre a autoridade, a define como um processo de interpretação do poder, tal acepção "levanta a questão de quanto o sentimento de autoridade está nos olhos de quem vê" (SENNETT, 2001, p. 33). Assim, o narrador se constitui como uma autoridade que guia o olhar para que as relações desiguais sejam vistas, desvendando o autoritarismo. Sennett localiza a Revolução Francesa como um marco do pensamento moderno na mudança de linguagem da rejeição da autoridade. A autoridade antes localizada na política, com a decapitação da ficção pessoal do Rei, que inibia os revolucionários a provocarem mudanças sociais, espalha a dominação por toda parte. "Os que lideram revoluções são tão senhores quando os que defendem a Igreja e o rei. A liberdade provém de se expulsar o 'senhor dentro de si', sejam quais forem suas exigências" (SENNETT, 2001, p. 63). Já no século XIX, o espírito de negação da autoridade espraiou-se para a economia.

Tornou-se uma arma pela qual as pessoas procuravam defender-se das forças do mercado e do crescimento industrial, que estavam transformando a sociedade europeia e norte-americana. [...] As doze horas diárias de trabalho de uma criança nas minas eram explicadas como um benefício para a sociedade e, em última análise, para a própria criança (presumindo-se que ela sobrevivesse); o mercado estava distribuindo a todos os recursos do mercado de trabalho. A destruição da economia agrícola era um benefício semelhante para a sociedade: os agricultores desapropriados haviam ficado "livres" para vender seu trabalho pelo melhor preço, no mercado aberto. Não menos do que Marx, pareceu a Disraeli um perigo terrível que as pessoas que sofriam com a nova ordem industrial viessem a acreditar nessas coisas; nesse caso, tanto a mente quanto o corpo seriam escravizados. (SENNETT, 2001, p. 64) 
Pensamos que não é preciso comentar as consequências de tal lógica em contextos periféricos como o do nordeste brasileiro; das aldeias africanas; ou mesmo das regiões rurais da península ibérica semelhantes à desenhada no enredo de Bandeira Preta. Lembremos ainda que tal lógica exploratória era agravada pela situação política repressiva neocolonial, no caso de Moçambique; pela ditadura salazarista, em contexto português; e pela aparente transformação do regime, com o tenentismo liberal e a política getuliana, que mais proporcionaram uma convivência entre as oligarquias regionais e a nova burguesia industrial nos centros urbanos, no caso brasileiro (ver BOSI, 1994, p. 383-384). Enfim, foram tempos de perseguições, ditaduras - como se sabe, Honwana e Graciliano Ramos foram presos - e de expansão do fascismo pelo mundo.

Quanto à linguagem, as narrativas de Honwana se aproximam de Vidas Secas. Há nas duas obras a presença de repetição das palavras, notadamente em adjetivações, ou em imagens. Em Vidas Secas, o papagaio morto e devorado, fora da diegese, é elemento que retorna em memória que deve ser esquecida, testemunho da fome extrema que aniquila mesmo aquilo em que se deposita afeto; o desejo de Sinhá Vitória pela cama de Tomás da Bolandeira, signo de aproximação do saber, da estabilidade, da vida aos seus e a ela negada; o desejo de Fabiano em vingar-se do soldado amarelo, expressão da força descabida do Estado contra seu ser humilhado; a cachorra Baleia morta a tiros por Fabiano, retorna à memória assim como o papagaio devorado, sentenciando que, caso permanecessem, "ele, a mulher e os dois meninos seriam comidos" (RAMOS, 1992, p. 114).

Em Nós matamos o Cão-Tinhoso, precisamente no conto homônimo que abre o livro, além da relação mais evidente com Vidas Secas, a presença de um cão em contexto de violência, temos a imagem recorrente do Cão-Tinhoso a olhar cheio de feridas; tal como o muçulmano, o intestemunhável conceituado por Agamben, nos fazendo pensar sobre o instável valor da vida, sobre a banalização do mal. Em "Inventário de Imóveis e Jacentes", conto da mesma obra, lê-se a descrição dos poucos cômodos de uma casa onde vivem seis pessoas, o apego da Mamã ao colchão de sumaúma, comprado de segunda mão, um luxo na casa apertada em que todos dormem em colchões de palha, usado pelos filhos para descansar, principalmente pelo menino-narrador, uma vez que "a Mamã disse que a preguiça é um defeito feíssimo numa mulher” (HONWANA, 1980, p. 38), argumento empregado para afastar suas irmãs Tina e Lolota do colchão. Impossível aqui não nos lembrarmos de Sinhá Vitória e seu desejo pela cama de Seu Tomás da Bolandeira que, nessa comparação, ganha outra dimensão: a de desejo de descanso da vida dura de retirante, ao mesmo tempo, de fuga inconsciente do signo do trabalho incessante ao qual as mulheres são submetidas por uma tradição que sequer elas têm condições de questionar.

Em "A Velhota", conto ainda de Nós matamos o Cão-Tinhoso, o adolescente humilhado fora de casa não deseja voltar a ela, e quando em casa lê seu entorno como extensão da humilhação sofrida na rua: "E pre- 
cisava ir para casa para encher os ouvidos de berros, os olhos de miséria e a consciência de arroz com carril de amendoim” (1980, p. 55). Impossível não nos remetermos ao desejo de Fabiano de abandonar a família e entrar em um bando de jagunços, desejo este logo interditado por conta da existência da família, o que lhe enchia de ódio, assim como ao narrador de "A Velhota": "E eu sem poder rebentar exatamente por causa do raio da velhota e dos ranhosos dos miúdos" (1980, p. 55). Ao entrar em casa, o narrador vê seus irmãos dividindo e brigando por parca comida, e sua mãe a negar a fome para que ele coma.

No conto "Nhinguitimo", que encerra o livro de Honwana, temos narrada por um adolescente a história de um jovem conhecido como Vírgula Oito, que tem a sua força de trabalho explorada de modo aviltante e que, ao fim, enlouquece, mata seus companheiros e é assassinado, como já explicitamos acima. $\mathrm{O}$ conto encerra com o narrador indiferente a toda violência vista, indicando que ela está também no silenciamento dos que testemunham e nada fazem, tema que igualmente faz parte do conto homônimo que abre o livro Nós Matamos o Cão-Tinhoso. "Nhinguitimo" curiosamente abre com a aparição de arribações de rolas, lembrando o capítulo "O mundo coberto de penas", de Vidas Secas, em que as arribações de pássaros pressagiam o mau. A rola, "uma das aves mais antipáticas da criação", como descreve o narrador, aproximam-se também em arribações antes do início da colheita, e passa a ser descrita pelo narrador como uma ave sem poesia, sem lirismo, e nos parece que aqui há uma reflexão sobre a própria linguagem e sobre as motivações estéticas da construção da narrativa da ficção de Honwana:

Ninguém se lembra de ter visto uma rola a deixar-se embriagar pela carícia do vento, como frequentemente acontece à andorinha [...].

Com os olhinhos negros sempre vigilantes, a rola viaja na esteira dos grãos e volta pontualmente todos os anos [...].

O seu cantar não tem tempo de ser musical, é imediatamente triste; é uma espécie de refilanço rouco e agreste. Às vezes, sendo monótono é descritivo e nostálgico. Nunca, porém, poético ou divagante: é sempre horrivelmente direto.

Cantando, a rola não lamenta, como fazem muitos outros pássaros, acusa. Entristece o vale. (HONWANA, 1980, p. 78-79, grifo nosso)

Através da descrição da rola, do seu ser e do seu canto, é possível pensar na própria construção narrativa da prosa de Honwana, que apresenta semelhantes traços: ao dar testemunho de "não-vidas", vidas esquecidas, a linguagem precisa ser direta, telegráfica, seu objetivo não é o lamento, mas espraiar um sentimento vivido na paisagem que parece ocultá-las. Sua literatura, portanto, procura expor formas invisíveis e tristes de existência, amalgamadas na imagem das arribações de rolas. 
Em Vidas Secas também é possível visualizar a presença de uma explicação sobre o estilo da prosa que compõe o romance, em destaque a presença da estratégia da repetição. No capítulo central da narrativa, "Inverno", já mencionado neste artigo, os meninos ouviam, deitados de forma desconfortável no colo da Sinhá Vitória, o pai contando façanhas, porém o menino mais velho, ao ouvir a narrativa do pai, se desgosta e tece críticas, nos enviando a uma explicação para o uso do recurso da repetição:

O menino mais velho estava descontente. Não podendo perceber as feições do pai, cerrava os olhos para entendê-lo bem. Mas surgira uma dúvida. Fabiano modificara a história - e isto reduzia-lhe a verossimilhança. Um desencanto. Estirou-se e bocejou. Teria sido melhor a repetição das palavras. Altercaria com o irmão procurando interpretá-las. Brigaria por causa das palavras - e a sua convicção encorparia. Fabiano deveria tê-las repetido. Não. Aparecera uma variante, o herói teria se tornado humano e contraditório. (RAMOS, 1992, p.68, grifo nosso)

A repetição, a revivência das palavras, que o filho vê ausente na narrativa do pai, é constante nas imagens da narrativa de Graciliano Ramos. A presença da repetição, conforme o narrador indica através do foco narrativo onisciente (seletivo múltiplo), na personagem do menino mais velho, objetiva dar corpo à verossimilhança, ao pacto do leitor com o constructo ficcional, sua crença na verdade da narrativa. Leonel Cherri, no artigo "La repetición como experiencia", ao escrever sobre a imagem, nos lembra que ela

[...] 'se define como diferente (héteron) respecto a aquello a lo que se refiere' (Álvarez Asiain, 2011, p. 131). Esa 'diferencia de sí, ahora en la boca de Deleuze, subraya el carácter creativo de la imagen: su 'producir o inventar el aspecto 'visible' de lo que carece de toda visibilidad [...] como quien intenta acercar a la visibilidad aquello que, propiamente, seria invisible' (Pardo, 2004, p. 543-544). [...]. Por tales razones, para Deleuze, la imagen acabó presentándose como potencia de pensamiento. Al igual que para Emanuele Coccia, [...] la imaginación es el fundamento de lo humano. (CHERRI, 2017, p. 4-5)

Dessa forma, para além de compreendermos a presença da repetição de palavras e imagens como traço de reforço da verossimilhança narrativa, ou ainda como sintoma característico de trauma em contextos violentos, a imagem também sobreleva o fundamento do humano, uma vez que a presença do humano ante a realidade desumana se dá através da criação, do desejo e do sonho figurado tanto nas obras de Honwana e Ramos, notadamente em suas metáforas de leitura do mundo: os pássaros do mau-agouro vistos por Fabiano e sonhados por Sinhá Vitória, por exemplo; ou os animais, Baleia e Cão-Tinhoso, e os sentidos elaborados na criação, no processo de fazer deles imagem. Entretanto, Antonio Candido não localiza na formulação de imagens o traço característico do humano, mas na invenção da interioridade, sendo esta, para o crítico, a estratégia adotada por Ramos para estabelecer a humanidade aos seres postos à margem: 
Nesse sentido, lembro que a presença da cachorra Baleia institui um parâmetro novo e quebra a hierarquia mental (digamos assim), pois permite ao narrador inventar a interioridade do animal, próxima à da criança rústica, próxima por sua vez à do adulto esmagado e sem horizonte. O resultado é uma criação em sentido pleno, como se o narrador fosse, não um intérprete mimético, mas alguém que institui a humanidade de seres que a sociedade põe à margem, empurrando-os para as fronteiras da animalidade. (CANDIDO, 2006, p. 149)

Concordamos com Candido ao identificar uma aproximação da família para "as fronteiras da animalidade", ao expor os pensamentos infantis e rústicos da cachorra Baleia, contudo, não podemos deixar de observar o papel ambíguo da repetição que, ao mesmo tempo, pode sugerir uma pobreza criativa (os assuntos giram em torno das mesmas imagens na mente de Baleia, como seria na mente de uma criança rústica ou dos adultos espoliados) e, por outro lado, pode também indicar uma criação que se deseja vista, que insiste, persiste em se fazer visível, como escreve Cherri.

Dos três livros aqui estudados, o de autoria de Branquinho da Fonseca é o menos seco em sua linguagem, sua prosa é onírica em descrições da natureza e da paisagem. Como observou Pierre Houcarde, há toda uma temática que redunda em sua contística [Zonas, Caminhos Magnéticos, Rio Turvo, O Barão, Bandeira Preta] e que comprova a presença, em sua narrativa, do signo do sonho: a noite; a água; a viagem involuntária ou inexplicada; a morte, são temas recorrentes nos enredos de suas obras, e todas eles estão presentes em Bandeira Preta. Houcarde, na ocasião da morte de Fonseca, escreve que considera Bandeira Preta

[...] a mais apurada [...], a mais equilibrada também e a mais subtilmente construída de todas as colectâneas de Branquinho da Fonseca. Nesses contos o humor nunca está longe da ternura, e nunca, por outro lado, se cai na pieguice desenxabida. As evocações dos tempos felizes não são pueris, concedem um lugar amplo e necessário quer ao mistério quer ao sofrimento e à miséria, e até à morte, brutal e injusta, paredes meias com as brincadeiras, as aventuras e as fantasias do mundo das férias. (HOUCARDE, 1975, p. 50-51)

Leonor, Pedro e Chinca são apresentados no primeiro conto, homônimo ao título da obra, como três amigos que, em brincadeira, navegam um barco contra a corrente. A bandeira preta em um mastro aponta para um dado transgressor das crianças, nela ainda estava bordado um símbolo mais mouro do que cristão, como descreve o narrador. Sobre isso, Benjamin Abdala Jr. nos lembra que:

Os primeiros colonizadores da América Latina vieram da região que os árabes chamaram de Al-Ândalus. "Algarve" provém de Al-Gharb al ândalus (Andaluzia Ocidental), que abrangia o atual Algarve e o baixo Alentejo. A maior parte da população de Lisboa, na época dos Descobrimentos, so- 
me-se a essas constatações, era de origem moura. Eram culturalmente híbridas, para onde confluíram muitas culturas da bacia cultural mediterrânea. Alargando as observações, poderíamos afirmar que a bacia mediterrânica, na perspectiva de um campo que se organiza em rede, constitui um nó multívoco, pelos cruzamentos histórico-culturais entre a Europa, África e Ásia. No processo de colonização das Américas, seu repertório híbrido e polissêmico veio a misturar-se ainda mais pelas interações com os povos ameríndios e africanos. (ABDALA JR., 2016, p. 247-248)

A remissão ao que Abdala denomina hibridismo cultural português surge em diversas passagens da obra de Fonseca, uma delas no capítulo/conto "Os Anjos", quando os amigos exploram uma mina do "tempo dos romanos, uma minha de chumbo" (FONSECA, 1966, p. 45), tomada hoje por tufos de ervas e paredes forradas de "veludos de musgo e finas avencas pendentes", eles visualizam "restos esboroados de paredes de habitações ou currais. Talvez usassem qualquer coisa equivalente às modernas vagonetas, nesse tempo puxadas por cavalos, ou escravos... Deviam ser escravos... E dormiam ali" (1966, p. 46). Noutra, ao subirem um velho moinho abandonado, donde dos buracos das paredes "saíam coelhos e ouriços-cachaceiros, cobras e salamandras, que para ali trouxera como estranha fauna admirar" (1966, p. 63-64), ao encontrar a porta escancarada pensam em algum invasor "vilão de fora dos muros, inimigo apostado sem rei nem lei. Alá é grande? Ah miseráveis! À guerra santa! Razias e incêndios, cabeças roladas e escravos vendidos!" (1966, 63-64). No conto "Histórias da Meia-Noite", João Meco, empregado da quinta, conta histórias de assombração ao Pedro e à cozinheira; uma delas, a mais extensa, é da moira encantada do fundo do Poço de Alça-Perna. Ao final do causo, após ter sua narrativa contestada, João Meco sentencia: "Vocês acreditam em almas de outro mundo e não acreditam em moiros, que foi um povo que já houve antigamente? Aí está como é o vosso juízo" (Idem, p. 140-141). Tal como arqueólogos, em palimpsestos, os meninos vão revelando a história turbulenta, em suas "assimetrias imperiais dos fluxos culturais", como conceitua Abdala Jr., da região onde brincavam.

Essa assimetria também surge, e se aprofunda, na relação dos amigos Pedro e Chinca enquanto crescem. Como em Vidas Seca e Nós matamos um Cão-Tinhoso, há também um cão, agora de nome Leão, cão de Chinca, que mereceu, assim como Baleia, um capítulo intitulado com seu nome. Antes se sabe que Pedro é filho de donos de uma quinta, mas aqui a situação desigual dos amigos fica evidente; nesse momento, o leitor descobre que Chinca morava em um casebre, já havia passado pela experiência da fome, e o nome dado ao cão, de Leão, rei dos animais, soa compensatório da realidade humilde, assim como Baleia, que, em seu nome, compensa a realidade da seca.

No capítulo/conto "Leão", em que os meninos, acompanhados do cão de Chinca, o Leão, foram espiar uma infantaria, a imagem de Chinca 
vai aos poucos se definindo. Em um conflito com um civil da comunidade, o cão Leão avança e é morto a tiros, Pedro segura o amigo Chinca, que, com uma navalha em punho, lutava com o amigo para poder vingar-se da morte de Leão. Vendo seu impulso frustrado, Chinca toma Leão morto nos ombros e emudece. Em sofrimento, outra imagem do amigo se revela ao Pedro: "de cara dura e sorriso amargo, que, nos seus dezesseis anos castigados de pobreza e trabalho, tinha por vezes um ricto de velhice precoce" (1966, p. 82-83). No conto "O Ninho", a imagem de Chinca como um menino natural se reforça, nessa ambientação ele era superior, pois:

Conhecia os ventos e o correr das nuvens, as ervas de comer e os tortulhos venenosos. E estas ciências misteriosas, juntas ao instinto de bicho fino, davam-lhe uma superioridade de rei da selva e tornavam-no um companheiro ambicionado por toda a gaiatada dos arredores. Mas não era dado a confiar, pois naquelas andanças os companheiros são de melhores ausências que de boas ajudas. Só Pedro, não por pergaminhos de menino rico, [...] tratava Chinca de igual para igual, era companheiro desejado e conveniente. (FONSECA, 1966, p. 99)

Durante uma caçada com Chinca, em uma conversa sobre os animais, Chinca demonstra ter raiva dos bichos que matam os outros e Pedro justifica-os pela fome, que Chinca revela também sentir, o que espanta o amigo. Chinca não trabalhava na Quinta da Várzea, de propriedade da família de Pedro.

E ainda bem. Passaria de companheiro a criado [...]. Miséria por miséria, antes moço de moleiro e caçador furtivo.

- Também sou lobo... ou milhafre... Por isso tenho tento, não me metam algum zagalote no coiro. Quando quiser ganhar dinheiro, já tenho quem me pague a passagem para o Brasil ou para o Congo. Aqui é que ele não se ganha. É lá, a esfolar pretos e lagartos...

- Depois chamam-te o brasileiro.

- Ou isso...Já estou habituado a chamarem-me nomes. (FONSECA, 1966, p. 102)

Toda a hierarquia animal de devoração em nome da sobrevivência é, na conversa dos amigos, transferida para a hierarquia entre as nações. África e Brasil, no imaginário de Chinca, o marginalizado em sua sociedade de origem, são espaços onde a lógica se inverteria. Pouco depois Chinca amarra e tortura Pitanga, filho do Sardinheiro, acusando-o de ter mexido no ninho de rola; Pedro não concorda com a crueldade do castigo, embora não se oponha; porém, depois volta para soltar Pitanga. Essa passagem nos remete ao signo da rola no conto de Honwana, formas não vistas de existência, que na novela de Branquinho da Fonseca tem a sua posse disputada por Chinca e Pitanga, também formas de vida invisibilizadas, os dois meninos são de origem e vida humildes. 
Em "O Jurro", a metáfora da rola retorna, agora em uma caçada com o amigo, eles encontram Jurro, guardador de videiras, de feias feições e de família também marginalizada pela aparência física. Sempre escorraçado, Jurro sem querer pisa na mão de Pedro, que deseja vingança, também incitada pelo amigo Chinca; tal vingança se dá durante uma caçada de rolas, Pedro atinge um olho de Jurro, que imediatamente cega. Chinca, no entremeio, desarma Jurro e os dois ainda o levam à delegacia, justificando a não intencionalidade do ato de Pedro. Logo depois, Jurro é novamente desarmado e morto em uma briga de bar. Jurro é socialmente inferior a Chinca, e ambos inferiores a Pedro, que sai ileso de sofrer qualquer consequência pelo crime que cometera. Tais contos parecem assim oferecer uma visão complexa da sociedade colonizadora, revelando uma "desconstrução dos mitos e a distopia”, como escreve Abdala Jr. ao tratar das múltiplas formas de pós-colonialismo, também presente em narrativas do ex-colonizador.

No conto "Olhos deslumbrados" há uma mudança significativa na narrativa: temos uma primeira pessoa desconhecida, possivelmente Pedro, mas a narrativa se passa nos açores. Caso seja Pedro o narrador, fica suposto que a família exilara-se por algum motivo oculto na obra. ${ }^{12}$ Sugerimos que Pedro seja o narrador, pois há uma vinculação temporal que não é perdida, o narrador adolesce nesse conto e no capítulo seguinte, "Um peixe gordo", Pedro retorna para a quinta depois de um tempo distante.

Em "Olhos Deslumbrados", o narrador tem uma namorada, Alayde, filha de D. Almerinda, nascida no Brasil, em uma fazenda de cana-de-açúcar. Seu pai, Sr. Basílio, enriquecera no Brasil e aqui casara com D. Graciliana, curioso nome da personagem brasileira, descrita da seguinte forma: "D. Graciliana, velhinha magra que eu via raras vezes e parecia esconder-se no fundo da casa, numa vida de bicho subterrâneo 13 e perseguido" (1966, p. 181). Impossível não pensar aqui em um diálogo com Graciliano Ramos, em uma remissão ao autor e seus personagens subterrâneos e perseguidos, ou mesmo na situação periférica brasileira, sobrelevada pela personificação feminina elaborada por Branquinho da Fonseca. A personagem de D. Graciliana é descrita, não gratuitamente, próxima ao "preto Domingos, já de cabelos brancos, que passava o dia a arranjar hortas, à noite se sentava à porta da cabana de tábuas, no fundo da quinta, a tocar violão, mas que quando o Sr. Basílio falava tinha um ar de humilde e assustado" (1966, p. 181).

Em Bandeira Preta, Branquinho da Fonseca parece assim refletir sobre as relações de poder embutidas entre Portugal, Brasil e África. Não há, portanto, em Bandeira Preta, assim como em Nós matamos o Cão-Tinhoso, ou mesmo em Vidas Secas, a "celebração, seja de mimese ou de um pretenso hibridismo, que desconsidera as relações de poder e encaminha atitudes assimilacionistas tendentes à cultura do colonizador" (ABDALA JR., 2016, p. 254). E no caso da narrativa produzida em espaço português, exemplificado aqui pela leitura de Bandeira Preta, temos uma demonstração do pós-colonialismo do ex-colonizador que revela e problematiza mitos, ${ }^{14}$ elaborando um mapeamento do apagamento das tensões presentes 
no passado fundador da nação portuguesa, apagamento que será encarnado pelas crianças em determinados contextos em que a hierarquia da valoração das vidas, regidas por critérios biológicos, nacionais e de classe, se impõe.

Abdala Jr. indica que, no Brasil, os estudos de literatura comparada, em decorrência da nossa história, objetivaram verificar as bases da colonização do nosso imaginário, importante e necessário para o nosso autoconhecimento, contudo sugere outra forma de comparatismo:

[...] para figurar ao lado desse primeiro, que com ele acaba por se imbricar na prática comparatista. Um comparatismo prospectivo, pautado por relações comunitárias, um comparatismo da solidariedade, da cooperação. Comparar diante de problemáticas que nos envolvem a todos para nos conhecer naquilo que temos de próprio e em comum. Enlaces comparatistas, tendentes a relações de reciprocidade (ABDALA JR., 2016, p. 250 -251).

E, certamente, observar as configurações do autoritarismo e da violência nas narrativas literárias de língua portuguesa pode ser uma via para encarar o problema, em suas mais diversas facetas, que insistentemente, e infelizmente, se faz presente nas comunidades afro-ibero-americanas, uma vez que estão inseridas em todo um sistema de opressões, silenciador daqueles que não se encaixam nos considerados padrões de civilização e modernidade.

\section{REFERÊNCIAS BIBLIOGRÁFICAS}

ABDALA, Jr., Benjamin. Comunitarismo literário-cultural e a globalização: os países de língua portuguesa. In Journal of Susophone Studies 1. 2, p. 246-261, Autumm, 2016.

. Literatura, cultura e comunitarismos. In SECCO, C. L. T., SAlgado, M. T. \& JORGE, S. R. (Orgs.). Pensando África: Literatura, arte, cultura e ensino. Rio de Janeiro: Fundação Biblioteca Nacional, 2010, p. 144-153.

AGAMBEN, Giorgio. O que resta de Auschwitz. Trad. Selvino J. Assmann. São Paulo: Boitempo, 2008.

BENJAMIN, Walter. Magia, técnica, arte e política. Trad. Sérgio Paulo Rouanet. 7a Ed., São Paulo: Brasiliense, 1994.

BOSI, Alfredo. Tendências Contemporâneas. In História Concisa da Literatura Brasileira. 35a ed., São Paulo: Cultrix, 1994.

BUENO, Luís. O Romance do Outro: Vidas Secas (a. e b.). In: Uma história do romance de 30. São Paulo: Editora da Universidade de São Paulo; Campinas: Editora da Unicamp, 2006, p. 64-664. 
Antonio Candido leitor de Graciliano Ramos. In: Revista Letras, Curitiba: Editora UFPR, n. 74, p. 71-85, jan./abr. 2008.

CANDIDO, Antônio. Ficção e confissão: ensaios sobre Graciliano Ramos. Rio de Janeiro: Ouro sobre azul, 2006.

CHAVES, R. \& MACEDO, T. (Orgs.) Marcas da diferença: as literaturas africanas de língua portuguesa. São Paulo: Alameda, 2006.

CHERRI, Leonel. "La repetición como experiencia”. In Revista da Associação Brasileira de Literatura Comparada - ABRALIC, v. 18, n. 28, 2017. Disponível em: <http://revista.abralic.org.br/index.php/revista/article/ view/392/384>. Acesso em 04/08/2017.

CRISTÓVÃO, Fernando. Graciliano Ramos estudado em França. In: Revista Colóquio/Letras. Notas e comentários, n. 14, p. 62-65, Jul. 1973.

FONSECA, Branquinho da. Bandeira Preta. $2^{\text {a }}$ ed., Lisboa: Ed. Portugália, 1966.

HONWANA, Luís Bernardo. Nós matamos o cão tinhoso. São Paulo: Ática, 1980.

. Literatura e o conceito de africanidade. In: CHAVES, R. \& MACEDO, T. (Orgs.) Marcas da diferença: as literaturas africanas de língua portuguesa. São Paulo: Alameda, 2006, p. 17-25.

HOUCARDE, Pierre. Homenagem a Branquinho da Fonseca. In: Revista Colóquio/Letras. Ensaio, n. 23, p. 47-51, Jan. 1975.

MAGALHÃES, Belmira. A particularidade artística: a relação entre o local e o universal em Graciliano Ramos. In ARAÚJO, H. H. \& OLIVEIRA, I. T. de (Orgs.) Regionalismo, Modernização e Crítica Social na Literatura Brasileira. São Paulo: Nankin, 2010, p. 41-63.

MELLO, Alfredo César Barbosa de. Antropófagos devorados e seus desencontros: da "formação" à "inserção" da literatura brasileira. In Literatura e Sociedade, n. 22, 2016. Disponível em: <https://www.revistas.usp.br/ ls/article/view/123483>. Acesso em 07 de janeiro de 2017.

OLIVEIRA, Irenísia Torres de. Fantasia e crítica nos livros sertanejos de Graciliano Ramos. In: ARAÚJO, H. H. \& OLIVEIRA, I. T. de (Orgs.) Regionalismo, Modernização e Crítica Social na Literatura Brasileira. São Paulo: Nankin, 2010, p. 65-77.

RAMOS, Graciliano. Vidas Secas. 62 a ed., Rio de Janeiro, Record, 1992.

SANTIAGO, Silviano. O entre-lugar da literatura latino-americana (1971). In: Uma literatura nos trópicos: ensaios sobre dependência cultural.

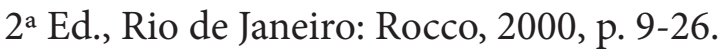

SEIXO, Maria Elzira. Recensão crítica a "Nós matamos o cão-tinhoso", de Luís Bernardo Honwana. In Revista Colóquio/Letras. Recensões críticas, n. 16, Nov. 1973, p. 81-82. 
SENNETT, Richard. Autoridade. Trad. Vera Ribeiro. Rio de Janeiro: Record, 2001.

TRIGO, Salvato. A emergência das literaturas africanas de expressão portuguesa e a literatura brasileira. In Letras de Hoje, vol. 1, n. 1, 1984. Disponível em: <http://revistaseletronicas.pucrs.br/ojs/index.php/fale/article/ view/17587/11319>. Acesso em: 06 de abril de 2017.

WELLEK, René. A crise da literatura comparada. In: COUTINHO, Eduardo F. \& CARVALHAL, Tânia Franco (Orgs.) Literatura comparada: textos fundadores. Rio de Janeiro: Rocco, 1994, pp. 108-119.

\section{Recebido para publicação em 09/11/2017 \\ Aprovado em 09/02/2018}

\section{NOTAS}

$1^{*}$ Professora de Literaturas de Língua Portuguesa do Departamento de Estudos da Linguagem e docente permanente do Programa de Pós-graduação em Estudos da Linguagem, na Universidade Estadual de Ponta Grossa/PR. Doutora em Literatura pela UFSC (2009). Autora do livro A comunidade em exílio: literatura comparada entre Lima Barreto e Roberto Arlt, publicado pela Editora Annablume (2013).

2 Abdala Jr., ressonando uma perspectiva também presente no pensamento de Edward Said, não vê as obras desvinculadas, "desde os tempos da expansão europeia e mundialização da economia capitalista, à dinâmica de interações dos fluxos culturais, sempre pautados pela assimetria e pela imposição dos padrões hegemônicos" (2016, p. 246). Porém, acreditamos que o professor/pesquisador não deve, em seus exercícios de leitura crítica, pautar-se pela lógica de fonte e influência que muitas vezes perpetua tal assimetria, sem criticidade, como já observara Silviano Santiago na década de 70, no ensaio "O entre-lugar do discurso latino-americano" (SANTIAGO, 2000).

3 Rita Chaves é cuidadosa ao afirmar que se trata de um diálogo entre estas literaturas, e que tal diálogo não nos autoriza "a atribuir ao repertório brasileiro um papel maior do que o que efetivamente foi seu, isto é, não devemos acreditar que ele alterou o quadro cultural dos países africanos, mas apenas reconhecer a importância dessa relação que se instaurou e a sua potencialidade no processo de dinamização das reflexões que internamente ganhavam força" (CHAVES, 2006, p.43).

4 Única incursão de Honwana pela literatura, Nós matamos o cão tinhoso foi publicado quando o autor tinha apenas 22 anos e traduzido para várias línguas. Em 2001, seu livro foi indicado como um dos cem melhores do continente africano. Engajou-se na luta pela independência de Moçambique, o que o levou a prisão nos anos 60. Foi Ministro da Cultura, em Moçambique, e, entre 1994 e 2002, ocupou o cargo de representante da UNESCO na África do Sul.

5 Foi dramaturgo, poeta, contista e um dos fundadores da revista Presença, além de outras revistas; em 1930, rompe com o grupo presencista. Sua prosa também não está filiada ao grupo neorrealista, sabidamente muito tocado pela obra de Graciliano Ramos. Criou o primeiro projeto de biblioteca-itinerante, em 1953, em Portugal. Posteriormente, em 1959, dirigiu o Serviço de Bibliotecas Itinerantes da Fundação Calouste Gulbenkian, e daí em diante não publicou mais nenhum livro de criação pessoal.

6 Maria Alzira Seixo também aponta este elemento, o uso da primeira pessoa narrativa como um traço de união entre os contos (ver SEIXO, 1973).

7 Conto que inspirou o filme Deixe-me ao menos subir às palmeiras, longa-metragem de Joaquim Lopes Barbosa, de 1972. 
8 Em seu artigo, Oliveira nos chama a atenção para o fato de Graciliano Ramos publicar, alguns anos depois, em 1944, Histórias de Alexandre, que é repleto de histórias orais de valentia, satirizadas, pelo cego Firmino, que atrapalha o narrador, e cita Lins, que já observara que nessa narrativa o sonho é compensatório, mas desencantadas pelo humor. Esse contraste entre a ausência de oralidade e a presença excessiva em outro reforça a "hipótese de que esta supressão relaciona-se com a busca de uma unidade narrativa férrea" (OLIVEIRA, 2010, p. 69).

9 Nesse artigo, intitulado "Literatura e o conceito de africanidade", Honwana vê nas criações literárias moçambicanas um espelhamento da sociedade, contudo, reconhece que ainda não se abriu espaço para que outros universos linguísticos, de outros possíveis escritores, "possam vir a se acrescentar as nossas vozes, na representatividade também linguística que a nossa literatura não pode deixar de ter como objectivo" (2006, p. 23).

10 Nessa passagem também fica evidenciada a relação do animal como elemento que habita o limiar dentro/fora da hierarquia de valoração da vida. Tema também presente em Vidas Secas e Bandeira Preta.

11 Fernando Cristóvão comenta o estudo quantitativo do estilo de Graciliano Ramos em Vidas Secas, de autoria de Jean Roche, o qual afirma que Ramos alcança o máximo de efeito com o mínimo de meios, através de denso vocabulário. Nesse passo, para Cristóvão, "de ora em diante não se poderá afirmar, sem mais, que a frase do autor de Vidas Secas é curta, que a elipse é o seu processo preferido, que predominam no texto as frases nominais e que a sobriedade de estilo repousa na parcimónia dos elementos constituintes" (CRISTÓVÃO, 1973, p. 62), uma vez que o estudo quantitativo de Roche revela o oposto. Porém, Cristovão percebe que tal levantamento de dados não consegue alcançar as razões da sensação de brevidade e a impressão de estarmos diante de um texto com linguagem seca. Nossa hipótese é a presença de imagens que se repetem, como trataremos mais adiante no corpo do artigo.

12 No conto "Leão", já analisado, há uma alusão à situação política de Portugal. Em um jantar da família de Pedro, com quatro convidados, o narrador diz: "Não se falou em revolução, nem de política, como se fosse assunto proibido ou que não interessasse a ninguém. Ouviu falar do Brasil, da América, do Congo Belga, da emigração e de negócios de passaportes falsos" (FONSECA, 1966, p. 73). Nesse trecho repleto de silêncios e interrupções, fica sugestionada a conversa do grupo sobre a fuga de um governo repressor.

13 Certamente aqui a descrição "olhos de bicho" refere-se ao capítulo "Fabiano", de Vidas Secas, em que a personagem oscila entre ser bicho e ser homem. Enquanto o narrador descreve o que o olhar de Fabiano captura no entorno, brotam curtos pensamentos sobre sua vida de bicho que se esforça para entocar-se, mas que é, a todo momento, expulsado como "judeu errante". Mas o termo que Branquinho da Fonseca utiliza para descrição de D. Graciliana é ainda mais próximo ao título de um ensaio de Antonio Candido, intitulado "Os bichos do subterrâneo", do livro Ficção e Confissão: ensaios sobre Graciliano Ramos, publicado pela primeira vez em 1956, mesmo ano de Bandeira Preta. Contudo, vale acrescentar que o crítico isola Vida Secas da leitura dos demais romances escritos em primeira pessoa. Luís Bueno escreve sobre o fato no ensaio "Antônio Candido leitor de Graciliano Ramos", e faz um exercício de inserção da família de retirantes na série de bichos do subterrâneo que Candido localiza na obra de Graciliano Ramos.

14 Benjamin Abdala Júnior trata do pós-colonialismo do ex-colonizador no romance Os cus de Judas, de António Lobo Antunes, e identifica nele uma "desconstrução de mitos" e um "fazer de memória individual que se quer história" (ABDALA JR., 2016, p. 252). Em Bandeira Preta, a história irrompe a partir de objetos encontrados pelas crianças, seja através dos livros ou das narrativas orais dos populares, como a do empregado da quinta da família de Pedro, João Meco, em "Histórias da meia-noite". 